\title{
Peningkatan Hasil Belajar Siswa Menggunakan Video Animasi Audiovisual Berbasis Animaker Pada Materi Sistem Gerak Manusia
}

\author{
Devi Kusumahwardani*, Ading Pramadi, Meti Maspupah \\ Pendidikan Biologi, UIN Sunan Gunung Djati Bandung, Indonesia \\ *Coresponding Author: devi.kusumawardani9@gmail.com
}

Article History:

Received 2021-11-14

Revised 2022-01-08

Accepted 2022-01-22

DOI:

10.31949/educatio.v8i1.1665

\begin{abstract}
The background of this research is the completeness of students' test scores in biology subjects. An innovation is needed to support the online learning process which is expected to improve student learning outcomes. This study aims to describe the application of animaker-based audiovisual animation videos to improve student learning outcomes in the buman motion system material. The method used is the pre-experimental method with a one-group pretest-posttest design. This research was conducted at One Roof Junior High School 1 Rawamerta for the academic year 2021/2022 with the research population being all VIII grade students and a sample of 30 grade VIIIA students. The instruments used to collect data are observation sheets, tests and questionnaires. The results showed that the teacher's learning implementation was in the very good category, while the student's implementation activities were in the good category. Students' responses to learning using animakerbased audiovisual animation videos were in the high category. The results of the average difference test of student learning tests showed that the posttest score was better than the pretest score. Thus, animaker-based audiovisual animation video media helps improve student learning outcomes.
\end{abstract}

Keywords: Audiovisual animation video; animation; learning outcomes; buman movement system

\begin{abstract}
Abstrak
Penelitian ini dilatar belakangi ketuntasan nilai ulangan siswa pada mata pelajaran Ilmu Pengetahuan Alam. Perlu dilakukan sebuah inovasi untuk menunjang proses pembelajaran daring yang diharapkan dapat meningkatkan hasil belajar siswa. Penelitian ini bertujuan untuk mendeskripsikan penerapan video animasi audiovisual berbasis animaker untuk meningkatkan hasil belajar siswa pada materi sistem gerak manusia. Metode yang digunakan yaitu metode pre eksperiment dengan design one group pretest-posttest. Penelitian ini dilaksanakan di SMPN Satu Atap 1 Rawamerta tahun ajaran 2021/2022 dengan populasi penelitian adalah seluruh siswa kelas VIII dan sampel siswa kelas VIIIA yang berjumlah 30 orang. Instrumen yang digunakan untuk mengumpulkan data adalah lembar observasi, test dan angket. Hasil penelitian menunjukkan keterlaksanaan pembelajaran guru memperoleh kategori sangat baik, sedangkan aktivitas keterlaksanaan siswa memperoleh kategori baik. Respon siswa terhadap pembelajaran menggunakan video animasi audiovisual berbasis animaker memperoleh kategori tinggi. Hasil uji beda rata-rata tes belajar siswa menunjukkan nilai postes lebih baik dibanding nilai pretes. Dengan demikian, media video animasi
\end{abstract} audiovisual berbasis animaker membantu meningkatkan hasil belajar siswa.

Kata Kunci: video animasi audiovisual; animaker; hasil belajar; sistem gerak manusia

\section{PENDAHULUAN}

Ilmu Pengetahuan Alam (IPA) merupakan ilmu yang mempelajari cara mencari tahu tentang alam dan peristiwa-peristiwa yang terjadi di alam meliputi alam semesta, benda-benda yang ada dipermukaan bumi, di dalam perut bumi dan di luar angkasa, baik yang dapat diamati langsung maupun tidak dapat diamati langsung secara sitematis dengan proses penemuan. IPA bukan hanya penguasaan kumpulan pengetahuan yang berupa fakta-fakta, konsep-konsep atau prinsip-prinsip saja tetapi juga merupakan suatu proses penemuan. Pendidikan IPA diharapkan dapat menjadi wahana bagi siswa untuk mempelajari diri yang berkaitan dengan 
cara mencaritahu tentang alam secara sistematis, alam sekitar, serta pengembangan lebih lanjut dalam menerapkana di dalam kehidupan sehari-hari. Pada dasarnya tujuan Ilmu Pengetahuan Alam (IPA) adalah untuk mendidik dan membekali untuk mengembangkan keterampilan-keterampilan dalam memperoleh dan menerapkan konsep-konsep IPA, serta memberikan bekal pengetahuan dasar siswa untuk melanjutkan ke jenjang pendidikan yang lebih tinggi maupun untuk diterapkan dalam kehidupan sehari-hari.Oleh sebab itu pembelajaran IPA sangat penting diajarkan di sekolah.

Namun kenyataanya beberapa penelitian yang mengungkap adanya permasalahan dalam pembelajaran IPA di sekolah, khususnya di Sekolah Menengah Pertama (SMP). Penelitian yang dilakukan Juliana (2018), Mikran et al. (2018), Murwanto (2020), Puspitasari (2019), dan Rahmawati (2018) menunjukkan hasil belajar siswa SMP pada mata pelajaran IPA masih rendah sehingga perlu ada upaya guru dalam meningkatkannya. Rendahnya hasil belajar siswa pada mata pelajaran IPA juga dialami siswa SMPN Satu Atap 1 Rawamerta Karawang. Berdasarkan studi pendahuluan di sekolah tersebut, terdapat permasalahan dalam proses pembelajaran IPA khususnya materi Biologi kelas VIII. Pada proses pembelajaran kali ini dilaksanakan secara daring (Dalam jaringan) dan proses pembelajaran yang monton sehingga menjadi kendala terhadap pemahaman peserta didik. Kurangnya pemahaman peserta didik terhadap materi biologi menyebabkan minimnya respon pada saat proses pembelajaran. Ini dibuktikan dengan hasil pemaparan guru IPA kelas VIII, bahwa pencapaian nilai peserta didik kelas VIII mata pelajaran IPA cukup rendah yaitu $60 \%$ peserta didik yang masih dibawah KKM. Adapun KKM pada mata pelajaran IPA yaitu 70 dengan hanya 40\% yang mencapai KKM tersebut. Permasalahan ini tentu harus segera ditemukan solusinya agar siswa tidak mengalami kesulitan dalam pembelajaran IPA.

Penelitian-penelitian sebelumnya melakukan upaya meningkatkan hasil belajar IPA dengan menerapkan model pembelajaran, diantaranya Model Pembelajaran Inkuiri Terbimbing (Juliana (2018), Model Pembelajaran Kooperatif Make A Match (Mikran et al, 2018), model Pembelajaran Kooperatif Tipe NumberedHead-Together (Murwanto, 2020), pembelajaran think pair share (Puspitasari, 2019), dan cotextual teaching and learning (Rahmawati, 2018). Ada juga penelitian yang menggunakan media pembelajaran seperti Media Video (Panggabean et al, 2021), media pembelajaran powerpoint (Permadi \& Mentari, 2020), media animasi berbasis macromedia flash (Situmorang \& Andayani, 2019), dan media pembelajaran berbasis game edukasi (Tirtamayasandi et al, 2018). Penelitian ini berupaya meningkatkan hasil belajar siswa dengan menggunakan media Video animasi audiovisual berbasis animaker.

Sebagai fasilitator pembelajaran, guru diharuskan memanfaatkan perkembangan teknologi dengan merancang strategi pembelajaran secara kreatif dan inovaitif. Media pembelajaran mampu mewakili penyampaian materi yang kurang mampu disampaikan oleh guru melalui pembelajaran konvensional (Prastowo, 2012). Materi yang terbilang abstrak dapat kongkret dengan adanya media pembelajaran (Arsyad, 2013). Keterlibatan media pembelajaran saat proses pembelajaran berlangsung akan menjadikan kualitas suatu pembelajaran lebih baik. Berbagai komponen penguasaan guru dalam mengimplementasikan pada proses pembelajaran yang didukung oleh media dan teknologi pembelajaran dapat meningkatkan prestasi belajar peserta didik. Media dan teknologi yang dimaksud merupakan alat peraga yang dapat dijadikan alat pembelajaran untuk mencapai tujuan.

Pemilihan media pembelajaran audiovisual karena media audiovisual merupakan jenis media yang mengandung unsur suara dan unsur gambar yang dapat dilihat. Media ini dianggap lebih baik dan lebih menarik karena mengandung dua unsur tersebut. Dengan adanya dua unsur tersebut dalam media pembelajaran, diharapkan mampu membantu siswa dalam proses pembelajaran karena siswa memiliki cara belajar yang berbeda-beda. Animasi akan terlihat menarik apabila dipadukan dengan warna dan teks. Dan animasi akan lebih sempurna jika ditambahkan bantuan efek suara/audio (Mashuri \& Budiyono , 2020). Animaker merupakan salah satu media yang dapat dijadikan alternative dalam media pembelajaran. Aplikasi animaker lebih mudah digunakan dan diakses oleh guru, karena aplikasi ini sudah tersedia di internet dan dapat digunakan secara gratis. Aplikasi animaker merupakan aplikasi yang dapat membuat gerakan-gerakan yang beragam dengan efek suara serta transisi yang menarik sehingga membuat kesan pembelajaran yang lebih berwarna dan menarik perhatian peserta didik (Munawar, Hasyim, \& Ma'arif , 2020). 
Berdasarkan latar belakang di atas, tujuan dari penelitian ini yaitu untuk mengetahui peningkatan hasil belajar siswa setelah menggunakan video animasi audiovisual berbasis animaker.

\section{METODE PENELITIAN}

Penelitian ini merupakan penelitian kuantitatif dengan menggunakan metode penelitian PreEksperimental dan design penelitian One Group Pretest-Posttest. Desain ini dilaksanakan pada satu kelompok tanpa adanya kelompok kontrol. Populasi penelitian adalah seluruh siswa kelas VIII di SMPN Satu Atap 1 Rawamerta tahun ajaran 2021/2022 dengan sampel penelitian adalah 30 siswa kelas VIII A.

Dalam mengumpulkan data, Instrument yang digunakan diantaranya adalah lembar observasi, soal tes dan angket. Lembar observasi digunakan untuk mengamati pembelajaran IPA di kelas VIIIA dengan menggunakan video animasi audiovisual berbasis animaker. Soal tes digunakan untuk mengetahui hasil belajar siswa sebelum dan sesudah perlakukan. Sedangkan angket digunakan untuk mengetahui respon siswa terhadap penggunaan video animasi audiovisual berbasis animaker. Teknik analisis data hasil belajar IPA menggunakan analisis statistik inferensial dengan melakukan uji beda terhadap rata-rata pretest dan post test (t-test). Ada pun data angket tentang respon siswa terhadap video animasi audiovisual berbasis animaker dianalisis secara deskriptif kuantitatif.

\section{HASIL DAN PEMBAHASAN}

Penelitian ini ingin mengetahui keterlaksanaan proses pembelajaran menggunakan video animasi audiovisual berbasis animaker, untuk mengetahui peningkatan hasil belajar siswa setelah menggunakan video animasi audiovisual berbasis animaker, dan untuk mengetahui respon siswa terhadap video animasi audiovisual berbasis animaker.

Hasil pengamatan aktivitas guru dan siswa dalam pembelajaran IPA di kelas VIIIA dengan menggunakan video animasi audiovisual berbasis animaker dapat dilihat pada tabel 1 dan 2 .

Tabel.1 Hasil Analisis Keterlaksanaan Aktivitas Guru

\begin{tabular}{ccl}
\hline Pertemuan & Persentase Keterlaksanaan & Kategori \\
\hline Pertama & $91,66 \%$ & Sangat baik \\
Kedua & $84,61 \%$ & Sangat baik \\
Rata-rata & $88,13 \%$ & Sangat baik \\
\hline
\end{tabular}

Berdasarkan Tabel 1, hasil rata-rata analisis keterlaksanaan aktivitas guru yaitu 88,13\% yang dikategirikan sangat baik. Meskipun pada proses pembelajaran tidak terlaksana 100\% akan tetapi hasil dari persentase yang didapatkan tetap memiliki kategori sangat baik. Dengan begitu proses pembelajaran yang berjalan secara online berjalan sangat baik. Menurut Yusuf (2017) proses pembelajaran dipengaruhi oleh beberapa faktor yaitu guru, siswa dan fasilitas. Sehingga untuk mencapai tujuan pembelajaran harus memenuhi tiga faktor tersebut. Proses pembelajaran dilaksanakan dengan variatif agar memberikan nuansa yang berbeda. Dengan begitu, ketika sebelum melaksanakan pembelajaran, guru sudah menentukan metode dan media pembelajaran yang akan digunakan.

Tabel.2 Hasil Analisis Keterlaksanaan Aktivitas Siswa

\begin{tabular}{ccc}
\hline Pertemuan & Persentase Keterlaksanaan & Kategori \\
\hline Pertama & $81.82 \%$ & Sangat baik \\
Kedua & $75 \%$ & Baik \\
Rata-rata & $78,41 \%$ & Baik \\
\hline
\end{tabular}

Berdasarkan Tabel 2, hasil rata-rata keterlaksanaan aktivitas siswa yaitu 78,41\% yang dikategorikan baik. Menurut Agustin, Nurul dan Rusdi (2017) aktivitas belajar yaitu kegiatan yang memiliki sifat secara fisik 
maupun mental, karena kedua sifat tersebut pada proses pembelajaran saling berkaitan sehingga dapat menghasilkan aktivitas belajar yang optimal. Pada proses pembelajaran dibutuhkan adanya kegiatan. Pada prinsipnya belajar merupakan berbuat, dimana dalam hal ini siswa melaksanakan kegiatan untuk mengubah tingkah laku.

Tabel.3 Hasil Analisis N-Gain

\begin{tabular}{lcccc}
\hline Data & & \multicolumn{2}{c}{ Kelas Eksperimen } & \\
& Nilai Tertinggi & Nilai Terendah & Rata-Rata Nilai & N-Gain \\
\hline Pretest & 60 & 25 & 44,17 & 0,4 (Sedang) \\
Posttest & 90 & 50 & 69,67 & \\
\hline
\end{tabular}

Berdasarkan Tabel 3, pada nilai tertinggi pretest selisih 30 dengan nikai tertinggi posttest, sedangkan pada nilai terendah pretest berselisih 25 dengan nilai terendah postttest. Dengan begitu, dari hasil analisis data $\mathrm{n}$-gain, pada hasil posttest memiliki kenaikan yang signifikan dari hasis analisis pretest. Dengan begitu, video animasi audiovisual berbasis animaker dapat membantu siswa dalam meningkatkan hasil belajar. Menurut Tafonao (2018) media pembelajaran merupakan segala seuatu yang digunakan sebagai alat untuk menyampaikan infomasi kepada penerima sehingga dapat merangsang, perhatian, pikiran, perasaan dan minat siswa untuk belajar. Proses pembelajaran dengan dibantu media animasi audio visual, mengajak siswa untuk memperhatikan, mendengarkan serta mendengar langsung informasi atau materi pembelajaran yang disampaikan langsung melalui pelantara video animasi audiovisual.

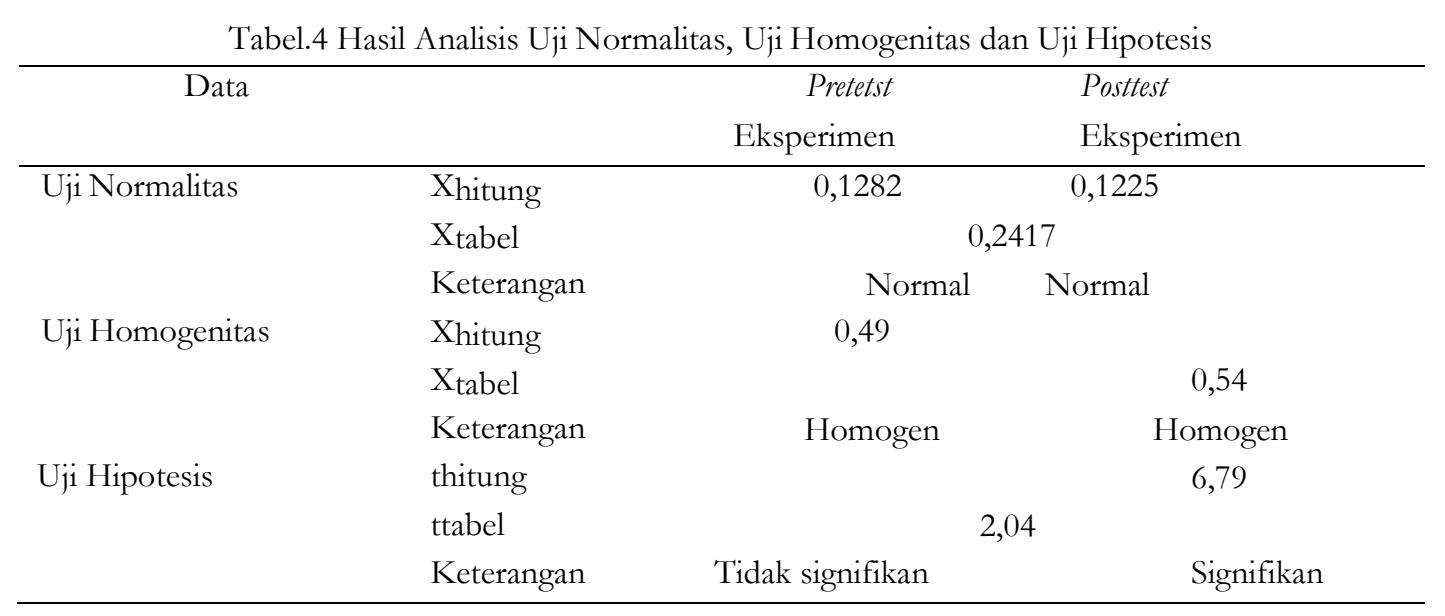

Pada Tabel 4, diketahui bahwa uji normalitas dan uji homogenitas menunjukan bahwa data berdistribusi normal dan homogen. Setelah itu pada uji hipotesis terdapat perbedaan yang signifikan antara data pretest dan data posttest, yang artinya pembelajaran menggunakan video animasi audiovisual berbasis animaker dapat membantu peserta didik untuk meningkatkan hasil belajar siswa pada materi sistem gerak manusia.

Menurut hasil data yang telah didapatkan selama penelitian, terdapat peningkatan hasil belajar setelah menggunakan media pembelajaran berupa video animasi audiovisual berbasis animaker. Dengan begitu, penerapan video animasi audiovisual berbasis animaker dapat membantu meningkatkan hasil belajar siswa. Hal ini didukung oleh Maheswari dan Puri (2021) bahwa dalam menciptakan suasana belajar yang menyenangkan, pendidik harus lebih kreatif dan inovatif dalam menciptakan sebuah media pembelajaran. Dengan begitu, diharapkan dapat memberikan pengaruh dalam menciptakan keinginan belajar siswa dan diharapkan dapat meningkatkan hasil belajar siswa. Keberhasilan belajar siswa harus ditingkatkan secara kontinu, motivasi belajar juga diperlukan untuk menghasilkan hasil belajar yang efektif dengan menyajikan bahan ajar yang dikemas menjadi sebuah media pembelajaran yang menarik. 
Hasil pengukuran respon siswa terhadap penggunaan video animasi audiovisual berbasis animaker dapat dilihat pada tabel 5. Berdasarkan analisis angket siswa terhadap pembelajaran menggunakan video animasi audio visual berbasis animaker memiliki rata-rata hasil sebesar $71 \%$ termasuk ke dalam kualifikasi yang tinggi, yang artinya bahwa respon siswa terhadap pembelajaran menggunakan video animasi audio visual cukup tinggi.

Tabel 5. Rekapitulasi Data Respon Siswa Terhadap Video Animasi Audiovisual Berbasis Animaker

\begin{tabular}{llcc}
\hline No & \multicolumn{1}{c}{ Indikator } & $\begin{array}{c}\text { Rata-Rata } \\
\text { Respon Siswa }\end{array}$ & Kriteria \\
\hline 1. & $\begin{array}{l}\text { Respon siswa terhadap penyajian materi sistem gerak } \\
\text { manusia }\end{array}$ & 73 & Tinggi \\
2. $\quad \begin{array}{l}\text { Respon siswa terhadap video animasi audio visual } \\
\text { berbasis animaker }\end{array}$ & 70 & Tinggi \\
3. $\quad \begin{array}{l}\text { Respon siswa terhadap soal yang diberikan. } \\
\text { Rata-Rata }\end{array}$ & 70 & $\begin{array}{l}\text { Tinggi } \\
\text { Tinggi }\end{array}$ \\
\hline
\end{tabular}

Hasil belajar siswa dapat meningkat karena adanya antusias dan respon pada siswa terhadap proses pembelajaran menggunakan media. Pada proses pembelajaran, penggunaan media dapat memungkinkan terjadinya peningkatan terhadap hasil belajar. Dengan adanya media pembelajaran tersebut dapat menarik perhatian siswa sehingga diharapkan proses pembelajaran dapat berjalan lebih baik. Pada penggunaan media pembelajaran berupa video animasi audio visual berbasis animaker ini juga memberikan dampak terhadap peningkatan hasil belajar siswa dengan memiliki nilai rata-rata akhir yang sedang. Dengan bergitu, media pembelajaran ini layak digunakan di kelas. Menurut Khairiyah (2019) respon siswa merupakan reaksi siswa atau tingkah laku selama mengikuti proses pembelajaran. Respon dapat muncul apabila melibatkan panca indera untuk mengamati objek. Dalam merespon sesuatu terdapat beberapa faktor yang memperngaruhi yaitu pengalaman, proses belajar dan nilai kepribadian.

\section{KESIMPULAN}

Hasil penelitian menunjukkan bahwa hasil belajar siswa pada mata pelajaran IPA setelah menggunakan media video animasi audiovisual berbasis animaker lebih baik dibandingkan sebelumnya. Hasil tersebut menunjukkan bahwa pembelajaran dengan menggunakan video animasi audiovisual berbasis animaker efektif dalam meningkatkan hasil belajar siswa pada mata pelajaran IPA, khususnya materi sistem gerak manusia.

\section{DAFTAR PUSTAKA}

Agustin, M. Nurul A, Y. Rusdi. (2017). Upaya Meningkatkan Aktivitas Belajar Siswa Dengan Menerapkan Model Pembelajaran Problem Posing Tipe Pre Solution Posing Di SMP Negeri 15 Kota Bengkulu. Jurnal Penelitian Pembelajaran Matematika Sekolah. 1(1), 66-72.

Asyhar, R. (2011). Kreatif Mengembangkan Media Pembelajaran . Jakarta : Gaung Persada Press.

Juliana, S. (2018). Penerapan Model Pembelajaran Inkuiri Terbimbing untuk Meningkatkan Hasil Belajar IPA Siswa Kelas VIII Semester II SMPN 5 Siak Kecil Kecamatan Siak Kecil Kabupaten Bengkalis. Jurnal PAJAR (Pendidikan dan pengajaran), 2(4), 530-539.

Khairiyah, ummu. (2019). Respon Siswa Terhadap Media Dakon Matika Materi KPK dan FPB Pada Siswa Kelas IV Di SD/MI Lamongan. Jurnal studi pendidikan dan keislaman. 5(2). 197-204.

Maheswari , G., \& Putri , P. (2021). Pengaruh Penggunaan Media Audio Visual Animaker terhadap Motivasi Belajar IPA Siswa Sekolah dasar. Jurnal Ilmu Pendidikan, 3(5), 2536

Mashuri , D. K., \& Budiyono . (2020). Pengembangan Media Pembelajaran Video Animasi Materi Volume Ruang untuk SD Kelas V. Jurnal PGSD, 08(05), 893-903. 
Mikran, M., Pasaribu, M., \& Darmadi, I. W. (2018). Penerapan Model Pembelajaran Kooperatif Make A Match untuk Meningkatkan Hasil Belajar Siswa Kelas VIIA SMP Negeri 1 Tomini Pada Konsep Gerak. JPFT (Jurnal Pendidikan Fisika Tadulako Online), 2(2), 9-16.

Munawar , B., Hasyim , A. F., \& Ma'arif , M. (2020). Desain Pengembangan Bahan Ajar Digital Berbantu Aplikasi Animaker Pada PAUD Di Kabupaten Pandeglang. Jurnal Golden Age, 4(2), 310-321.

Murwanto, S. (2020). Implementasi Model Pembelajaran Kooperatif Tipe NHT (Numbered-Head-Together) untuk Meningkatkan Hasil Belajar IPA Siswa Kelas IX B SMP Negeri 4 Alla Enrekang. Sainsmat: Jurnal Ilmiah Ilmu Pengetahuan Alam, 9(1), 14-28.

Panggabean, F., Simanjuntak, M. P., Florenza, M., Sinaga, L., \& Rahmadani, S. (2021). Analisis Peran Media Video Pembelajaran Dalam Meningkatkan Hasil Belajar Ipa Smp.JPPIPAI: Jurnal Pendidikan Pembelajaran IP A Indonesia, 2(1).

Permadi, A. S., \& Mentari, F. (2020). Penerapan Media Pembelajaran Powerpoint Untuk Meningkatkan Hasil Belajar Mata Pelajaran IPA Di SMP Negeri 1 Kahayan Kuala. Bitnet: Jurnal Pendidikan Teknologi Informasi, 5(1), 55-62.

Prastowo, A. (2013 ). Panduan Kreatif Membuat Bahan Ajar Inovatif. Yogyakarta : Diva Press. Tafonao , T. (2018). Peranan Media Pembelajaran Dalam Meningkatkan Minat Belajar Mahasiswa. Jurnal Komunikasi Pendidikan, 2(2), 103-114

Puspitasari, S. (2019). Upaya meningkatkan hasil belajar ipa dengan menggunakan model pembelajaran think pair share. Jurnal Global Edukasi, 3(1), 55-60.

Rahmawati, T. (2018). Penerapan model pembelajaran ctl untuk Meningkatkan hasil belajar siswa sekolah Dasar pada mata pelajaran IPA. Jurnal Ilmiah Pendidikan dan Pembelajaran, 2(1), 12-20.

Situmorang, R. P., \& Andayani, E. P. (2019). Penggunaan Media Animasi Berbasis Macromedia Flash untuk Meningkatkan Hasil Belajar Siswa pada Konsep Materi Sistem Peredaran Darah Manusia. Assimilation: Indonesian Journal of Biology Education, 2(1), 35-41.

Tirtamayasandi, A. P., Sukirman, S. T., \& Sujalwo, M. (2018). Perancangan Media Pembelajaran Berbasis Game Edukasi Untuk Meningkatkan Pemahaman Materi Gerak Lurus Ipa Smp (Doctoral dissertation, Universitas Muhammadiyah Surakarta).

Wuryanti, U. Badrun, K. (2016). Pengembangan Media Video Animasi Untuk Meningkatkan Motivasi Belajar dan Karakter Kerja Keras Siswa Sekolah Dasar. Jurnal Pendidikan Karakter. 7(2). 232-245. 